\title{
FRONTO AVUS: THE TALE OF A GRANDFATHER ${ }^{1}$
}

\section{J-M Claassen (Stellenbosch University)}

This paper examines some examples from the correspondence of the secondcentury rhetor, the Romanised African M. Cornelius Fronto, in particular letters that relate to the death of his grandson, drawing conclusions about Fronto as grandfather and as a person who had sustained previous bereavements. His attitude to his daughter $\mathrm{Cratia}^{2}$ and son-in-law Aufidius Victorinus receives special attention. The question of why Fronto seems to favour Victorinus over his own daughter when both are plunged into grief is addressed. It seems that in the grief of the younger man the older relives the agonies of his own youth, when he and his wife lost a series of children before bringing up Cratia as an only child.

The letters of M. Cornelius Fronto, the second-century African rhetor from the colony of Cirta, are most often quarried for the insights they provide into the imperial circle of Marcus Aurelius, Fronto's favourite pupil, and into matters oratorical. This paper will, however, concentrate on Fronto as family man, and, more particularly, on his emotions as husband, father and grandfather.

In the context of a study of Plutarch's consolation of his wife on the death of their little daughter, (Claassen 2004: 34-37) I weighed evidence on the high rate of infant mortality in the ancient world, also quoting Plutarch's assertion (Numa 12.2) that Numa strictly rationed mourning for infants in archaic Rome. I further discussed conflicting assumptions by modern critics about the emotional involvement of parents in their very young children. Wiedemann (1989) assumed reluctance in Roman parents, given the extremely likely possibility that such infants would die within the first year, to invest too much emotion in babies, lest they be almost permanently in a state of mourning over a lost little one. Such a death could have been considered a blessing, as in the Hellenistic East where epigrams on the death of a child often stated that the child had reached the summit of perfection, with the implication that its death should be considered timely (so Strubbe 1998). ${ }^{3}$ This attitude, so Wiedemann, changed under Jewish and Christian influence at about the turn of our era. I there argued that there was possibly always a discrepancy between custom and rule, and that, after the turn of our era, tradition was tempered by new attitudes that allowed for more open display. It was always considered muliebre for men to mourn openly: this

1 A shorter version of this paper was read at the $27^{\text {th }}$ biennial conference of the Classical Association of South Africa at the University of Cape Town, July 2007. Thanks to an anonymous reader for Akroterion for suggestions that improved this paper in various ways.

2 Both Fronto's Loeb editor, Haines, and the Brill editor, Van den Hout, use the variant spelling "Gratia", but Champlin 1980:26-7 argues convincingly from the Greek version of the mother's name at M.Caes. 2.12.1 (= Epist. Graec. 2.1), "Krateia", that initial "C" is preferable in Latin. He considers that Fronto's wife, the elder Cratia, may have come from a "highly cultured and politically powerful Greco-Roman" family background.

3 See my discussion 2004:32 of similar sentiments in Latin, from sepulchral monuments listed by Lier 1903-4 passim. 
would be left to the bereft mother, who was, however, also expected to display some restraint (Cic. Fam. 9.20.3, Sen. Ad Marc. 2.3-4; 7.3, Tac. Agr. 29.1; Plut. Cons ad $u x .4)$.

Mark Golden (1988) similarly weighs these and other arguments for and against parental grief at the loss of infants, and although he warns against our ascribing our own thoughts and feelings to the ancients, comes to the conclusion that emotional reactions to death and loss could not have changed over-much across the centuries. He cites modern anthropological studies of societies where infant life is considerably endangered and argues that, even in those cases of extreme poverty that had led to women having to make a type of "Sophie's Choice" (about which child to keep and which to allow to die), such mothers' grief was profound.

The very high infant mortality rate at Rome (two-thirds of live births did not reach the age of ten years) would have affected not only parents, but other family relationships, especially the ties between grandparents and their grandchildren. ${ }^{4}$ Roman patria potestas as described in the Twelve Tables gave the pater, as head of a family, power over even adult children, and also control over his sons' children, unless their fathers had been freed from this control by means of a formal manumission ceremony. Over the children of their daughters they often had less control, unless these daughters had remained in manu patris after marriage. ${ }^{5}$ Yet at least three cases of maternal grandfathers' care for, and control over, their daughters' children are well known. Their reactions to these young children were, however, very different.

The emperor Augustus adopted his daughter Julia's sons Gaius and Lucius and later sent their brother Agrippa Postumus into exile. The deaths of the first two as young adults were a source of great grief to him but their supposedly illegitimate baby niece, child of Julia Minor, born after her mother's banishment, was summarily exposed on behest of its great-grandfather (Suet. Aug. 65). Earlier, Cicero had taken into his home his daughter Tullia and her baby, little Lentulus, infant son of Caesar's lieutenant Dolabella, when her marriage to Dolabella was dissolved. Cicero's grief at her death is well-attested, but we have no idea of how he felt about the almost simultaneous death of baby Lentulus. Cicero may have been resolutely applying the principle he quotes at Tusc. Disp. 1.93, that people did not always consider babies' deaths untimely, nor did they even mourn them. Yet he may simply not have cared so much for the baby: His ex-wife, the child's grandmother, was concerned, while little Lentulus still lived, that Cicero was not providing adequately for the infant in his will (Att. 12.18a). ${ }^{6}$

Against this apparent unconcern we have various letters from Fronto, to his former pupil Marcus Aurelius and to Marcus' brother Lucius Verus. The fond grandfather in one instance proudly tells of the wonders of his grandson and

\footnotetext{
$4 \quad$ For comparative figures relating to infant mortality see my paper (2004), passim, but especially nn. 10, 12 , also pp 34 to 37, with nn. 19 to 21, 29 and 35, where further authorities are cited and figures quoted.

5 Gaius $1.55 ; 2.86-7$, Inst. Just. $1.9 ; 2.9$. These late sources codify practices in many cases extant since the XII Tables.

6 Cf. Dixon 1988:55-56, Claassen 1996:219-223.
} 
namesake, the child of his daughter Cratia (the only one of Fronto's own children who had survived infancy). This boy was apparently (probably together with another youngster) being brought up in his maternal grandfather's house while their parents went north for an extended stint of official business. ${ }^{7}$ In a second set of letters (De nepote amisso 1 and $2,{ }^{8}$ Ad Verum Imperatorem 9 and 10), Fronto mourns the death, in Germany, of Cratia's third boy, a child in its third year, that he had not yet seen. He displays deep grief and a yearning love for the little boy he had never even held in his arms. De nepote amisso 2 may be read as "anti-consolatio," from the manner in which Fronto cites, and then refutes, the traditional commonplaces of philosophical consolation. This will be the major theme of my discussion below.

From his letters we come to know Fronto as an interesting man, who was much loved by his former imperial charges, and highly respected at Rome, both as orator and as arbiter of literary style. Writing in Greek, as he sometimes did, Fronto said of himself that he was "a Libyan of the Libyan nomads" (Ad. M. Caes 1.10.5 / Epist. Graecae 1.5). ${ }^{10}$ His thoroughly Romanised family had left Africa when he was still very young, and there is no record of his ever going back, but he seemed always to have maintained an interest in the affairs of his native city (Champlin 1980:19). $\mathrm{He}$ was also either very sickly or a consistent valetudinarian and the letters have frequent references to his state of health.

Fronto's corpus of letters was apparently as prone to ailments as their author, and many have been handed down to us in a very fragmentary state. Various editors have tried in different ways to make sense of these fragments, and the two editions I consulted (Loeb and Brill) differ quite considerably in their interpretation of the potential layout of at least one of the letters that are here of interest. My paper will, however, examine the extant remnants of these letters for their emotional content, rather than for their conjectured original format. Of particular interest is the second set, to aid us in drawing conclusions about Fronto as grandfather and as a person who had sustained previous bereavements. His attitude to his daughter Cratia and son-in-

7 Ad amicos. 1.12. Champlin 1974:155 dates this letter to ca. late 164, early 165 AD, suggesting that it postdates the death of the toddler, who would thus have been born in late 161, and that one of the two boys here mentioned (whom he identifies as M. Aufidius Fronto, cos. 199 AD, and C Aufidius Victorinus, cos. 200) could have been born subsequently to the little one's death. Champlin's 1980 monograph does not repeat the suggestion but gives the postulated birth dates of the two boys who attained adulthood as, respectively, 160 (or earlier) and 165/6, which would imply the same. However, see note 11 below.

8 The letters are also sometimes termed De nepotis amissione. I have chosen to keep to the shorter term.

9 Champlin 1980:7 and 26) discusses Fronto's pretense of comparative barbarity in his use of Greek, ascribing it to a "pose" in the leading proponent of Latin archaism at Rome. Fronto did, in fact, quite often write in tolerable Greek.

10 Double referencing is used here because C. R. Haines, the Loeb editor (1919-1920), arranges the letters from the various collections to different addressees in a conjectured chronological order, irrespective of the language used, while Brill's editor, M. P. J. Van Den Hout 1954 arranges them in separate chapters according to language, addressee and topic (hence the letters about the death of the little boy are grouped together as a chapter entitled De nepote amisso, pp. 220-24). In cases of discrepancy, I give both references. Quotations are from the Loeb edition, unless otherwise specified. 
law Aufidius Victorinus will receive special attention. The question of why Fronto seems to favour Victorinus over his own daughter when both are plunged into grief will be addressed.

The African Fronto had a particularly good relationship with the Roman Victorinus, a very capable and useful senator and rhetor in his own right. This is obvious not only from their mutual correspondence, but also from references to Victorinus in letters to others. Fronto had apparently on occasion acted as forensic patron for the citizens of Cirta, but later advised them to apply to Victorinus and two prominent Africans at Rome for further advocacy, citing both their forensic eminence and the interest of all three in matters African (Ad am. 2.11, Champlin 1980: 10,11). When Victorinus went to Germany, where Victorinus took up a post as propraetorian legate, Cratia accompanied him while at least one of their two older boys stayed behind with Grandpa. During this time the elder Cratia, Fronto's wife and the mother of the younger Cratia, apparently took ill and died, but the first specific mention we have of her death is at the close of a long letter with which we shall deal below.

Fronto was clearly a doting grandfather. In Ad amicos 1.12 he tells the boys' father about his little grandsons, relating playfully that he has daily lites et iurgia (tiffs and quarrels) with the two little fellows. ${ }^{11}$ He says no more than that about young Victorinus, but dotingly dwells on his little namesake. Little Fronto's favourite word was apparently Da! ("Gimme!"), a demand that filled Fronto avus with pride, although he was careful to add that he was attempting to give the boy every

11 There is some confusion about dates. Fronto refers here to two grandsons, little Fronto and little Victorinus. Ad am. 1.12 is dated by Haines 1919: ad loc to 164 AD, when young Fronto could have been about four years old, if we accept Champlin's dating of his birth to 160 (1980:28), but we cannot then accept Champlin's date of 165/166 for the birth of young Victorinus, identifiable as C. Aufidius Victorinus (cos. Ord. 200 AD, CIL XI 6335). Champlin 1974 solves this apparent contradiction by supposing that this letter postdated the letters on the loss of the toddler as this boy must have been born before this letter was written. Yet I surmise that the boy that bore his father's names would more probably have been older than young Fronto. Also, this letter clearly refers to Cratia's next pregnancy (the grandfather prays for the gods' favour for his daughter, apparently in the context of her imminent accouchement). Hence the letter must predate the birth of another child, the baby who died (on whom see below). Haines dates the De nepote amisso collection to 165 , that is, not long before the earliest acceptable death date for Fronto Senior himself (between 167 and 175, so Champlin 1980:139-2). If we accept either late 165 or early 166 for the baby's death, which we know preceded Lucius Verus' datable return to Rome in 166, Ad am. 1.12 must be dated to 163 at the latest, for the then-unborn baby to have been in its third year when it died (see Ad Ver. Imp. 2.9 and n. 19 below). The two older boys must then have been born in the first two years after their parents' marriage (conjecturally dateable to about 158), that is, in 159 and 160, before their parents' setting off for Germany in 161. Such an early date for this letter would more easily explain young Fronto's selfish manners (a clear indication of his being in his "terrible twos" — or "threes", if Roman dating is used), his relatively small vocabulary and even his "mumbling" enjoyment of grapes. It would also not exclude my theory that young Victorinus was the elder of the two, in spite of his brother's later gaining the consulship in 199, a year before he did. As Champlin 1974:156 himself states, it is possible that during the uncertain years following a change in imperial succession, either or both the young men did not achieve their consulships at the earliest possible date. It would seem that the younger man M. Aufidius Fronto, (the young Fronto of this letter) achieved his consulship a year before his older brother Victorinus. This Fronto erected an inscription to his son of the same name (CIL. XI.6334). 
opportunity, and an ample supply of pencils and writing paper, to develop his potential skills as writer and, ultimately, we may presume, as orator like his father and grandfather. Fronto is clearly an early example of the jocular modern aphorism that only grandparents are aware of the fact that there can be a perfect human being. Young Fronto's selfish demands were apparently a source of great pride to Fronto Senior. Even today maternal grandfathers have been known to favour the second boy (named after them) above the first-born boy named after its father or paternal grandfather. That would explain Fronto's fond description only of the wonders of little Fronto, and his comparative silence about young Victorinus (who did, at least, have the privilege of joining in the "daily tiffs and quarrels"). He delightedly tells the boys' father how little Fronto (clearly no more than two or three at the time) appears to resemble his grandpa's traits in his favouring of grapes (to eat) and small birds (presumably to play with). ${ }^{12}$

Yet Fronto was, unlike many other grandparents, not wholly fixated on his own descendants. Many doting grandparents wholly ignore other young children that they may encounter. We have a charming letter from Fronto to Marcus Aurelius, who would have been away from Rome at the time, describing an encounter with Marcus' two sons, the twins Aurelius Commodus and Antoninus Geminus (Ad Ant. Imp 1.3). Fronto refers to the two boys as Marcus' "chicks" (pullulis). Of them he says both are very well, with loud young voices (clamore forti, restrainedly translated by the Loeb editor, C. R. Haines, as "[they have] strong lungs)". One acted the real young prince, elegantly nibbling at a slice of white bread, whereas the other was the very offspring of a true philosopher, devouring a piece of coarse black bread. Fronto prays for the good health of the father and mother and of the boys and that many more such will be born of the imperial couple.

Reading between the lines, we discern here a hint of disappointment felt by Fronto as teacher of rhetoric that his former pupil had chosen to desert rhetoric for philosophy. The two boys together represent the two sides of his erstwhile pupil. For Fronto, oratory is the domain of purple-clad princes fed on luxurious fare. Philosophy can be relegated to the grubbers of meagre brown bread. Marcus replies (Ad Ant. Imp 1.4) that he clearly saw his own progeny in Fronto's description, but more, that he had also seen the author himself in his beloved master's words. Rather curiously, the father goes on to implore his former master to keep on loving him as he did when he, the writer of the letter, was also a child. It is almost as if Marcus is jealous of the love Fronto exhibits for the imperial children, his own offspring. Fronto's reply (Ad Ant. Imp 1.5) gently chides his correspondent for harking back to an undesirably unattainable, immature past state. Even here Fronto displays an understanding of the unsophisticated mind: only a nanny, he says, is envious of a young person's adolescence for taking her charge away from her. The implication is that Fronto is no nanny, but a master delighting in his former pupil's maturity.

Fronto was equally fond as husband. An early note to Marcus (Ad M. Caes. 2.10 Brill / 2.8 Loeb, dated by the Loeb editor to 143 AD) explains that he had sent his wife Cratia to visit the future emperor's mother at Naples. He promises that Cratia will not eat the imperials out of house and home, as she is no great eater, "as the

12 See Bradley 1998 on children's pet-keeping at Rome. 
wives of lawyers are said to be". The empress' kisses would be enough for her to feed upon. But, mourns the loving spouse, “... quid me fiet? Ne osculum quidem usquam ullum est Romae residuum. Omnes meae fortunae, mea omia gaudia Neapoli sunt""What is to become of me? There's not even a single kiss left anywhere in Rome. All my fortunes, all my joys are at Naples". Fronto yearns to leave office as consul prematurely in order to travel down to Naples to be with the source of all his joy, a topic that is continued in a (Greek) missive to the empress mother herself (Ad M Caes. 2.11 / Epist. Graec. 2), where its author's public office is likened to a shackle around his ankle.

In contrast to these playful missives are the letters of condolence and mourning ${ }^{13}$ which are the main focus of this paper: four, or, if we follow the editing of the Brill editor M. P. J. Van Den Hout (1954), six letters in all. De nepote amisso 1 conveys Marcus Aurelius' personal condolences to Fronto for a "misfortune" (de casu) that causes him great heartache. From the reply we learn that Fronto is in mourning. That the grandfather is mourning the death in Germany of the youngest child of Victorinus and Cratia emerges in the course of the bereaved grandfather's long letter. De nepote amisso 2 bespeaks abject misery. We learn, however, that this is not the first such loss that Fronto has had to bear. As father, he tells Marcus, he had himself mourned in turn the loss of five children, each at the time an only child ( $D e$ nep. am. 2.1). This means that in each case Fronto and Cratia Senior had expected their next child while mourning the loss of the previous infant. In all these cases, however, he had seen the infants before they died, probably held them in his arms: if not every day, then at least when raising them from the family hearth in customary recognition of their legitimacy. Hardest of all for the grandfather to bear now is the fact that he had never seen this little one before it died. The features of its older brother appear before his mind's eye when he tries to picture the dead baby, and it rends his heart. ${ }^{14}$ As a young father he could resist grief, but now, he, as the elder, shares the grief of another young father, and grief upon grief is multiplied: Victorini mei lacrimis tabesco, conliquesco (De nep. am. 2.2, I melt away in tears with my Victorinus, I dissolve in floods of weeping).

13 The fragmentary consolation to Herodes Atticus on the death of his first-born son, written at the request of Marcus Aurelius (Epist. Graec. 3) shows Fronto all-too humanly bearing the loss of another with far greater equanimity than he later does the loss to his own family. He assures Herodes that he is young enough to rear other children and advises him to rest in the love of the imperial prince. Ad amicos 1.20 commiserates with Sardius Saturninus on the loss of an adult son (apparently a pupil and house-mate of Fronto's) in terms typical of the consolatory tradition, relating the inability of the consoler to write an adequate letter, and adjuring the bereaved father to moderate his grief.

14 Champlin's assumption 1974:156 cannot be absolutely refuted, that one of the boys who later grew to adulthood had not yet been born at this time (see n. 11 above), but I should like to suggest that Fronto is here referring to little Fronto, because he would have been perhaps only two years or so older than the dead infant, and hence his "round baby- face" would have been more comparable to that of the departed infant than that of an older Victorinus. 
It would be easy to ascribe Fronto's emphasis on the loss sustained by his sonin-law, rather than dwelling on the grief of his bereaved daughter, to the general temper of the times, when men were regarded (by other men) as vastly more important than women, but there may be more to this apparently skewed approach. A detailed analysis of the various paragraphs of the letter seems called for.

The letter may be divided into sections. These seem to follow the general outlines of the prototypical consolation, but only in order to deny that Fronto derives any comfort from the tradition. ${ }^{15}$ The third paragraph concentrates on the nobility of Victorinus, the bereaved father, doubting the goodness of Providence for dealing such a virtuous man such a blow, even questioning the gods' unfairness in apportioning evil to a good man in a rhyming flourish, neque mensum neque pensum, "for no rhyme or reason" (De nep. am. 2.3). ${ }^{16}$ The next paragraph explores the staple of the consolatory tradition, the idea that death may be good in bringing eternal rest, a concept more acceptable to Fronto than the thought that Providence is either nonexistent or unfair. The argument that by dying young the little boy had been saved from the ills of the body is passionately refuted in Quod si verum licet, parvi nostra refert qui desideramus amissos: nec quicquam nos animarum immortalitas consolatur, qui carissimis nostris dum vivimus caremus (De nep. am. 2.5, "Even though this may be so, it helps us very little when we long for the ones we have lost, and the immortality of our souls does not console us while we, while we are still alive, are bereft of our little darlings"). Even if immortality of the soul is an established fact, he says it offers very little comfort to a heartbroken parent: non parentibus desiderandi remedium (ibid.).

The sixth paragraph refers to another staple of the consolatory tradition: the question of whether immortality or annihilation awaits the departed soul. An unfortunate lacuna prevents our finding out on which side the weight of Fronto's argument would here have come down, and the paragraph goes on to bewail the fact that the face of his living grandson racks Fronto's heart. In its lineaments, he says, he sees the face of the lost little one and in his voice he imagines the sounds of the unknown child: Hanc sibi dolor meus picturam commentatur. Verum defuncti vultum ignorans, dum verisimilem coniecto, maceror (De nep. am. 2.6, "This is the picture my grief thinks up for itself. Not knowing the face of the dead baby, while I imagine that it was just like his, I am lacerated by grief').

At last, in the seventh paragraph Fronto writes of Cratia, his daughter. Again her grief is filtered through the presumed reactions of her husband, the noble Victorinus: Sapiet mea filia: viro omnium quantum est hominum optimo adquiescet: is eam consolabitur pariter lacrimando pariter suspirando 〈pariter> loquendo pariter conticiscendo (De nep. am. 2.7, My daughter will be sensible: she will find peace in her husband's support, the very best man there can be. He will console her when he mingles his tears and sighs with hers, speaking with her when she speaks and

15 Buresch 1886 is still the standard reference work; the most recent available to me has been Johann 1968. See Claassen 1999: 83-85 on "anti-consolatio".

16 We should not assume that the rhetorical flourishes cannot indicate real emotion. An author known for his elegant and flowery style, when moved by great grief, will more naturally keep to the style to which he is accustomed, than to strip his style down to a new ascetic bareness. 
keeping silent when she is silent"). This loving and intimate picture of mutual support bespeaks affection for both spouses and an awareness of the course that grief must take. Yet Fronto also seems uncomfortably aware of the fact that he has so far virtually neglected his daughter's grief, and says excusingly that "such a husband is a better comforter" than senex ego parens. Another funerary commonplace (frequent on the graves of young people) is the thought that it would have been more fitting if he, an elderly man of an earlier generation, had himself died. The picture he gives us of Victorinus' ability to comfort the bereaved mother is perhaps also conventional, but nevertheless touching: Fronto's daughter's grief and pain would be better soothed by the words (vox) issuing from "lips so dear and a heart so near her own" ( $\langle e x\rangle$ ore carissimo et pectore iunctissimo profecta, De nep. am. 2.7).

As for himself, Fronto takes comfort in the thought that his life is almost over and death very near. Typically Roman (and to our modern taste immodest) self-praise concludes the eighth section. Fronto is conscious of a life well-spent in generous deeds and loving relationships. He had cultivated his mind, not his body, and, somewhat surprisingly, had "preferred poverty to the acquisition of wealth", a statement refuted by most of the evidence we have. Fronto's self-laudatory panegyric is continued in the next paragraph (De nep. am. 2.9), with praise of his own truthfulness and helpfulness to others. A serious lacuna, not wholly blank but consisting of a series of disjointed words, leaves us wondering what other noble characteristics or dismal sorrows the writer may have imputed to himself, and has led different editors to surmise differently about the ninth and tenth paragraphs. Haines (1920) attaches the fragmentary passage and the next paragraph to the body of this long letter, and Van den Hout (1954) divides paragraph nine (roughly in the middle of the fragmentary passage) into the conclusion of this letter plus a brief reply by Marcus (De nep. am. 3). ${ }^{17}$ The latter's edition then makes of Haines' "tenth paragraph" a brief reply from Fronto to this conjectured note (De nep. am. 4). Here at last we have a reference to the deaths of both Cratia senior and the little boy.

Taken either as a last paragraph or as a separate, short note, the intent is clear: Fronto has sustained severe losses, first his wife and then his grandson, and a "Decumanus", otherwise unspecified, but this may perhaps have been the name of the infant. Fronto's last words before ending with an allusion to a book that he has sent as representative of "everything" (presumably his thoughts), are: Ferreus si essem, plura scribere non possem isto in tempore (De nep. am. 2.10 Loeb, De nep. am. 4 Brill, "Had I been made of iron, I should not have been able to write more at that time"). ${ }^{18}$

17 Van den Hout's conjectural emendations of some of the fragmentary words differ in this passage from those of Haines. Most important for Van den Hout's reading of a separate missive from Marcus is the word that Haines reads as doleam ("I shall / should mourn ..."), which he makes into Doleo, $m<i \quad m>a g<i s t e r, v>e<r e>$; ("I'm truly sorry, my teacher ..."). The most complete part of the passage in both authors ends on what is clearly the thought that the gods must in time grant another child to Fronto's son-in-law and daughter: Dis placeat filiam generum ... ("May it please the gods that [my / your] daughter and son-in-law ..."). This sentiment is more likely to have emanated from a consoler rather than from the grief-stricken mourner. Hence I tend to favour Van den Hout's conjectured divisions.

18 The pluperfect subjunctives essem, possem indicate an "unreal condition in the past". This, together with the phrase isto in tempore, serves to strengthen Van den Hout's conjecture that this 
The next letter (Ad Ver. Imp. 2.9) is to Marcus Aurelius' brother Lucius Verus, this time starting with the loss of "the dearest of wives" (uxorem carissimam) and also mentioning the three year-old grandson, trimulum nepotem. ${ }^{19}$ By this time it would appear that Fronto has taken to heart the traditional consolatory precepts that the bereaved should turn to literature, and the letter continues quite cheerfully about matters literary and oratorical. Only the first paragraph of Verus' reply (Ad Verum Imp. 2.10) condoles with Fronto on his double loss. This letter is, however, again fraught with lacunae, and not much can be gained from it. In another letter to Verus, conjecturally several months later, but placed by Haines immediately after the letter of condolence, Fronto again, as so often, refers to his own ill health, but joyfully awaits Verus' return (Ad Verum Imp. 2.4). From all the evidence it would seem that Fronto did not long survive his wife and grandson. Edward Champlin (1980:141) conjectures that Fronto's demise was hastened by the plague that is known to have been brought to Rome by Verus' soldiers and that raged on for many years. ${ }^{20}$

Sic obiit Fronto avus. But why, we need to ask ourselves again, did he lay so much emphasis on the loss sustained by his son-in-law, admired and beloved though the younger man was by the elder? It seems as if the key is to be found in the first and seventh paragraphs of the long letter we have been considering. We have noted that Fronto starts with a reference to the calamities that have lifelong dogged his footsteps. Let alone any other catastrophes, he says, quinque liberos omnes unumquemque semper unicum amisi, has orbitatis vices perpessus, ut numquam mihi nisi orbato filius nasceretur. Ita semper sine ullo solacio residuo liberos amisi, cum recenti luctu procreavi (De nep. am. 2.1, "I lost five children, each an only child, so struck by this series of bereavements that no son was born to me when I was not bereft of another. And so I kept on losing children when I had no others left to comfort me, and with my grief still recent I begat another"). This means that each baby died while it was very young and no others had yet been born, and, with no child to console them, five times another baby was conceived while its parents were still grieving for the previous one. The sixth, successful conception and birth of a child that grew to adulthood produced the younger Cratia, the mother of all three of Fronto's grandchildren. One can only imagine with what anxiety each pregnancy after the first was fraught, and how anxiously each infant was watched as it failed to thrive. The elderly man remembers only his own grief, makes no mention of his beloved wife's reactions at the time, her fears and trauma.

We have also noted that only in the seventh paragraph does the grandfather refer to his daughter's grief, and then only in the light of the kind of comfort that will be afforded her by the loving and heroic Victorinus. This seems to me to be a reprise

is a separate letter, seeming to indicate that some time had elapsed before this passage was written, so that the phrase would be referring to the (earlier) time at which the author had written the long letter we have been examining.

19 This is the first time the age of the dead toddler is given, but, if we take in account the Roman manner of inclusive counting, the boy could have been just over two years old, that is, in its third year.

20 This fever was known as the "Antonine plague". It raged at Rome for many years and at last in 181 AD took off Marcus Aurelius himself, so Prof. Francois Retief of Bloemfontein (in a talk given at the $27^{\text {th }}$ biennial conference of the Classical Association of South Africa, July 2007). 
of the events of some eighteen to twenty-eight years earlier. We may imagine that Fronto as young father had five times over needed to repress his own grief in order to sustain his wife, keeping himself steady for her sake. He, too, would have "mingled his tears and sighs with hers, spoken when she spoke and kept quiet when she was silent". From his evocation of the type of consolation that Victorinus will offer the younger Cratia, we may extrapolate the sort of comfort the elder Cratia gained from her husband's support.

We are told in the second paragraph that in his youth this father had been able to control his grief, meus animus me $<$ o $>$ met dolori obnixus, oppositus quasi solitario certamine, unus uni par pari resistebat (De nep. am. 2.2, "my mind, struggling with my own grief, matched as if in single combat one to one, equal with equal, continued to resist). ${ }^{21}$ The young father had needed such strength of mind to be able to temper his profound grief to the fluctuations of his wife's equally deep emotion, as he now postulates Victorinus as doing. Here we have the key. Now as senex Fronto keenly shares in the emotional life of a young father who must struggle with his own sorrow in order to comfort an equally sorrowful wife. No longer does he need to keep his emotions at bay. In Victorinus' postulated mental anguish Fronto relives his own. Fronto knows all about such struggles: five times over he had been there, done that. That is why empathy for Victorinus predominates in this deeply sad letter.

\section{BIBLIOGRAPHY}

Bradley, K 1998. The sentimental education of the Roman child: the role of petkeeping. Latomus 57, 523-57.

Buresch, C 1886. Consolationum a Graecis Romanisque scriptarum historia critica. Leipzig: Teubner.

Champlin, E 1980. Fronto and Antonine Rome. Cambridge: Mass. Harvard University Press.

Champlin, E 1974. The chronology of Fronto. JRS 64, 136-59.

Claassen, J M 2004. Plutarch's little girl. AClass 47:27-50.

Claassen, J M 1999. Displaced Persons: the literature of exile from Cicero to Boethius. London: Duckworth.

Claassen, J M 1996. Documents of a crumbling marriage: the case of Cicero and Terentia. Phoenix 50:208-232.

Dixon, S 1988. The Roman Mother. London: Croom Helm.

Golden, M 1988. Did the ancients care when their children died? $G \& R 35,152-63$.

Haines, C R 1919, 1920 (ed.). The correspondence of Marcus Aurelius Fronto, vols. I \& II. London, Heineman: Loeb Classical Library.

Johann, H T 1968. Trauer und Trost. München: Wilhelm Vink Verlag.

Lier, B 1903-4. Topica carminum sepulcralium latinorum. Partes 1-2. Philologus 16:445-477; 563-603; Pars 3. Philologus 17:54-64.

21 Again we should remember that a mind schooled in rhetoric would in times of grief find it easiest to write in its customary style, and so we can accept that the rhetorical flourishes here still represent a deeply-felt emotion. 
Strubbe, J H M 1998. Epigrams and consolation decrees for deceased youths, $A C$ 67:45-75.

Van den Hout, M P J (ed.) M. Cornelii Frontonis epistolae vol. I. Leyden: Brill.

Wiedemann, T 1989. Adults and Children in the Roman Empire. London: Routledge. 